\title{
APA DAN MANA DALAM KALIMAT DEKLARATIF
}

Oleh :

Sri Puji Astuti

Fakultas Ilmu Budaya Universitas Diponegoro

\begin{abstract}
Kalimat merupakan salah satu sarana untuk menyampaikan maksud pembicara atau penulis kepada pendengar atau pembaca. Untuk menyampaikan informasi digunakan kalimat deklaratif. Dalam kalimat deklaratif sering ditemui kata apa dan mana serta bentuk turunannya. Bagaimana kehadiran apa dan mana serta bentuk turunannya dalam kalimat deklaratif dibahas dalam makalah ini. Teori yang digunakan untuk menganalisis adalah teori stuktural. Pengumpulan data dilakukan dengan cara menyimak pemakaian bahasa. Dalam analisis data digunakan metode distribusional yaitu metode analisis data yang berupa penghubungan aantarfenomena dalam bahasa tertentu itu sendiri Adapun teknik yang d.igunakan dalam penelitian ini adalah teknik delisi, substitusi, dan teknik parafrasa. Dari hasil penelitian disimpilkan bahwa apa dan mana serta bentuk tuturannya jika terdapat dalam kalimat deklaratif bukan merupakan interogativa. Kehadiran apa dan mana serta bentuk tuturannya dalam kalimat deklaratif ada yang bersifat wajib ada yang bersifat opsional. Apa dan mana serta bentuk turunannya bersifat opsional jika dalam kalimat deklaratif apa dan mana serta bentuk tuturannya diikuti atau didahului oleh kata yang mempunyai makna yang sama.
\end{abstract}

Kata kunci: apa, mana, kalimat deklaratif

\section{PENDAHULUAN}

Peran bahasa yang utama sebagai alat untuk menyampaikan maksud atau perasaan kepada orang lain sesuai dengan situasi kebahasaan. Untuk menyampaikan maksud tersebut digunakan kalimat. Kalimat yang digunakan pembicara maupun penulis dapat berupa kalimat interogatif, kalimat deklaratif, kalimat imperatif, dan lain-lain. Kalimat interogatif biasanya ditandai oleh adanya kata tanya apa, mengapa, siapa, dan lain-lain

Namun kenyataannya, kata apa, mana, dan bentuk turunannya itu selain dittemukan dalam kalimat interogatif, katakata tersebut juga ditemukan pula dalam kalimat deklaratif. Jika apa dan mana serta bentuk turunannya terdapat dalam kalimat deklaratif, bukan merupakan interogativa. Ramlan memberikan ciri kalimat deklaratif yaitu kalimat yang mempunyi intonasi berita (Ramlan, 1987:32). Lebih lanjut Ramlan memberikan ciri kalimat deklaratif yaitu tidak terdapat kata tanya seperti siapa, mengapa, di mana, dan kata kata ajakan seperti ayo, mari, serta kata-kata persilahan silakan dan dipersilakan, serta kata larangan jangan.

Alwi et al. (1993:265-266) berpendapat bahwa dilihat dari segi bentuknya, hanya ada dua unsur yang mendasari kata tanya apa dan mana. Kata apa dapat diturunkan menjadi bentuk lain misalnya siapa, mengapa, kenapa, keberapa dan lain-lain. Sedangkan kata mana dapat diturunkan menjadi di mana, ke mana, bagaimana, dari mana, dan lainlain. 
Berdasarkan latar belakang di atas dalam makalah ini diibahas Bagaimanakah kehadiran apa dan mana serta bentuk turunannya dalam kalimat deklaratif.

\section{KALIMAT DEKLARATIF}

Pengertian kalimat menurut Kencono (1982: 5) adalah satuan gramatikal yang disusun oleh konstituen berupa klausa, partikel penghubung jika ada dan intonasi final. Sejalan dengan Kencono, Cook (dalam Tarigan, 1984:8) berpendapat bahwa kalimat adalah satuan bahasa yang secara relatif dapat berdiri sendiri yang mempunyai pola intonasi akhir dan terdiri dari klausa. Dari kedua pendapat tersebut dapat disimpulkan bahwa kalimat mempunyai unsur klausa dan intonasi final.

Tarigan

mengklasifikasikan kalimat berdasarkan jenis responsi yang diharapkan menjadi tiga macam yaitu kalimat pernyataan, kalimat pertanyaan dan kalimat perintah. Kalimat pernyataan adalah kalimat yang dibentuk untuk menyiarkan informasi tanpa mengharapkan responsi tertentu. Kalimat pertanyaan adalah kalimat yang dibentuk untuk memancing responsi berpa jawaban. Sedangkan kalimat perintah adalah kalimat yang dibentuk untuk memancing responsi berupa tindakan atau perbuatan.

Alwi, et al. (1993:352) membedakan kalimat berdasarkan bentuk sintaksisnya, kalimat dapat dibedakan menjadi kalimat deklaratif, kalimat interogatif, kalmat imperatif, dan kalimat ekslamatif. Dalam penelitian ini hanya dibahas kalimat deklaratif. Kalimat deklaratif disebut juga dengan istilah kaimat berita. Ka;limat deklaratif merupakan kalimat yang tidak ada penanda khusus seperti kalimat interogatif ditandai oleh adanya kata tanya, kalimat imperatif ditandai oleh adanya kata ayo, mari, mohon dan sebagainya (Surono, 2011:110). Kalimat deklaratif ini dalam bentuk tulisnya diakhiri dengan tanda titik dan dalam bentuk lisan ditandai oleh nada turun. Kalimat deklaratif ini biasanya digunakan pembicara atau penulis untuk membuat pernyataan sehingga isinya merupakan berita bagi pendengar atau pembaca (Alwi, et al. 1993:353). Kalimat deklaratif adalah kalimat yang dibentuk untuk menyiarkan informasi tanpa mengharapkan responsi tertentu (Cook dalam Tarigan, 1985:20). Ramlan menyebutkan fungsi kalimat deklaratif yaitu untuk memberitahukan sesuatu kepada orang lain sehingga tanggapan yang diberikan hanyalah berupa perhatian seperti tercermin pada pandangan mata yang menunjukan adanya perhatian (1983:26).

\section{METODE PENELITIAN}

Metode merupakan cara kerja yang harus dijabarkan sesuai dengan alat dan sifat alat yang dipakai. Jabaran metode yang sesuai dengan alat dan sifat disebut teknik. Pengumpulan data dalam penelitian ini terjabar dalam wujud teknik dasar penyadapan. Tahapan ini berakhir dengan transkripsi ortografis yang berupa pencatatan pada kartu daata secara sistematis. Dalam analisis data digunakan metode distribusional yaitu metode analisis data yang berupa penghubungan aantarfenomena dalam bahasa tertentu itu ssendiri (Sudaryanto, 1982:13). Adapun teknik yang digunakan dalam penelitian ini adalah teknik delisi, ekspansi, substitusi, permutasi, dan teknik parafrasa.

\section{APA DAN MANA DALAM KALIMAT DEKLARATIF}

Perdasrkan hasil penelitian ditemukan kehadiran apa dan mana serta bentuk turunannya dalam kalimat deklaratiif ada yang bersifat wajib ada yang bersifat manasuka. Perhatikan contoh berikut ini.

(1a) Saya sering memikir-mikir pekerjaan apa yang kiranya tepat untuk Wayne. 
(1b) Saya sering memikir-mikir pekerjaan yang tepat untuk Wayne.

(2a) Siapa yang bersalah harus dihukum.

(2b) Orang yang bersalah harus dihukum.

(2c) Yang bersalah harus dihukum.

Dalam contoh (1a) apa dan dalam contoh (2a) siapa berfungsi untuk menggantikan sesuatu dan seseorang. Kehadiran apa dan siapa dalam kalimat tersebut bersifat opsional jika apa dan siapa tersebut diikuti oleh yang. Apa dan siapa dalam contoh (1a) dan (2a) jika dihilangkan tidak mengubah kegramatikalan kalimat seperti dalam contoh (1b) dan (2b). Dalam contoh (1c) yang berfungsi sebagai artikel yaitu membedakan kata di belakangnya.

Dalam contoh berikut ini kehadiran apa dan siapa bersifat wajib, contoh :

(3a) Kami siap melayani permintaan apa saja.

(3b) Kami siap melayani permintaan saja.

(4a) Wayne bangga. Katanya Steven pandai, tahu dengan siapa dia harus bersahabat.

(4b) Wayne bangga. Katanya Steven pandai, tahu dengan dia harus bersahabat.

Apa dan siapa dalam contoh (3a) dan (4a) dipakai untuk menggantikan sesuatu dan seseorang. Apa dalam contoh (3a) jika dihilangkan menjadi (3b). Contoh (3b) merupakan kalimat yang gramatikal tetapi bukan merupakan parafrase (3a). Jika siapa dalam contoh (4a) dihilangkan akan menjadi (4b).

Apakah dalam contoh di bawah ini berfungsi sebagai konjungsi, contoh :

(5a) Dia bertanya apakah saya tidak salah sasaran.

(5b) Dia bertanya apa saya tidak salah sasaran (5c) Dia bertanya saya salah sasaran apa tidak.

(5d) Dia bertanya saya salah sasaran atau tidak

(5e) Dia bertanya saya tidak salah sasaran.

(6a) Saya tidak yakin apakah saya mencintai sampeyan atau tidak.

(6b) Saya tidak yakin, saya mencintai sampeyan atau tidak .

(6c) Saya tidak yakin, saya mencintai sampeyan apa tidak.

Pada contoh (5a) kehadiran apakah bersifat wajib karena jika apakah dihilangkan, kalimat tersebut menjadi tidak gramatikal seperti pada contoh (5e). Apakah dalam contoh (5a) berfungsi sebagai konjungsi karena dapat disubstitusi dengan atau. Pada contoh (6a) apakah kehadirannya berifat opsional karena jika apakah dihilangkan tidak mengubah kegramatikalan kalimat seperti pada contoh (6b).

Kehadiran mengapa dan kenapa dalam kalimat deklaratif ada yang bersifat wajib ada yang bersifat opsional.

Contoh :

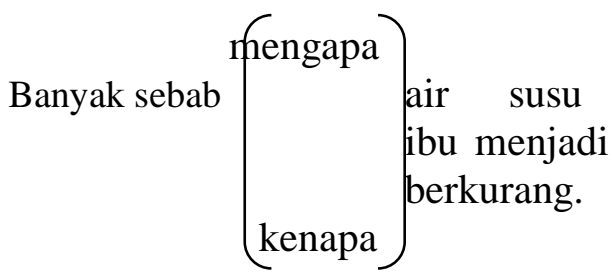

(7b) Banyak sebab air susu ibu menjadi berkurang.

Dalam contoh (7a) kehadiran mengapa dan kenapa bersifat opsional, jika didahului oleh sebab. Sebab mengapa dan sebab kenapa dalam contoh (7a) dipakai untuk mempertegas makna 'sebab' atau 'alasan'. Mengapa dan kenapa dalam contoh (7a) jika dihilangkan tidak mengubah kegramatikalan kalimat seperti pada contoh (7b). Dalam contoh (7a) sebab di situ dipakai untuk mempertegas makna 'sebab' sehingga kehadiran mengapa dan 
kenapa tersebut bersifat opsional. Akan tetapi, jika dalam contoh (7a) sebab dihilangkan maka kalimat tersebut menjadi tidak gramatikal seperti pada contoh (7c) berikut ini.

(7c) *Banyak $\left(\begin{array}{l}\text { mengapa } \\ \text { kenapa }\end{array}\right) \begin{aligned} & \text { air susu ibu } \\ & \text { menjadi } \\ & \text { berkurang. }\end{aligned}$

Contoh di atas, berbeda dengan contoh berikut ini.

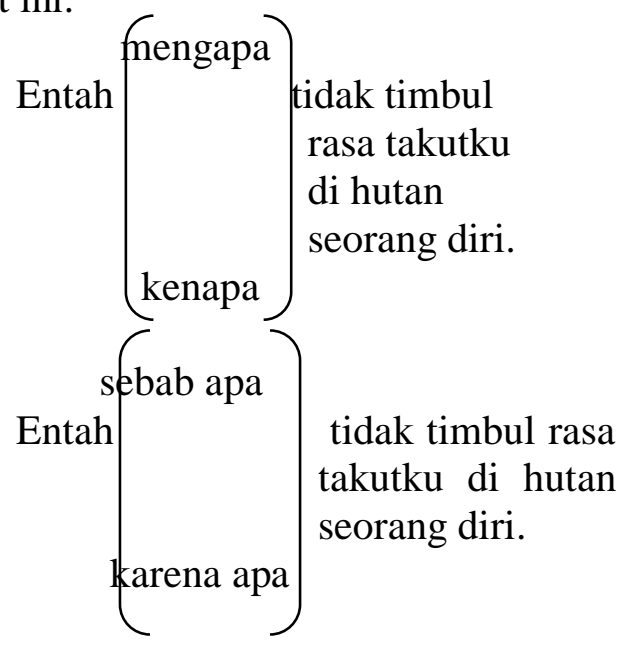

(8c) Entah tidak timbul rasa takutku di hutan seorang diri.

Dalam contoh (8a) mengapa dan kenapa dapat disubstitusi dengan sebab apa dan karena apa seperti pada contoh (8b). Mengapa dan kenapa dalam contoh (8a) dipakai untuk menandai makna 'sebab'. Jadi, kehadirannya bersifat wajib. Contoh (8c) merupakan kalimat yang gramatikal, tetapi bukan merupakan parafrasa contoh (8a).

Kehadiran berapa dalam contoh di bawah ini bersifat manasuka.

(9a) Saya belum mengerti berapa jumlahnya.

(9b) Saya belum mengerti jumlahnya.

Dalam contoh (9a) berapa merupakan numeralia tak takrif. Berapa dalam contoh (9a) kehadirannya bersifat opsional karena jika berapa dihilangkan tidak mengubah kegramatikalan kalimat seperti pada contoh (9b)

Contoh di atas berbeda dengan contoh berikut ini.

(10a) Tidak jelas benar berapa tokoh PKI yang divonis mati.

(10b) Tidak jelas benar tokoh PKI yang divonis mati.

Dalam contoh (10a) kehadiran berapa bersifat wajib, yaitu untuk menyatakan jumlah tak tentu. Contoh $10 \mathrm{~b}$ ) merupakan kalimat yang gramatikal, tetapi bukan merupakan parafrasa contoh (10a). Dengan demikian, contoh (10b) bukan merupakan bukti bahwa berapa dalam contoh (10a) bersifat opsional.

Dalam contoh di bawah ini kehadiran mana bersifat opsional.

(11a) Mereka tidak dapat membedakan mana tempat yang aman dan mana tempat yang berbahaya.

(11b) Mereka tidak dapat membedakan tempat yang aman dan tempat yang berbahaya.

Dalam contoh (11a) mana dipakai untuk menyatakan pilihan antara dua hal, dan kehadirannya dalam contoh (11a) bersifat opsional sehingga mana dalam contoh (11a) dapat dihilangkan menjadi (11b).

Kehadiran di mana dalam kalimat deklaratif ada yang bersifat wajib dan ada yang bersifat opsional, contoh:

(12a) Saya tidak tahu di manakah rumahnya.

(12b) Saya tidak tahu rumahnya.

Dalam contoh (12a) kehadiran $d i$ manakah bersifat opsional karena jika di manakah dihilangkan tidak mengubah kegramatikalan kalimat seperti pada contoh (12b). Di manakah dalam contoh (12a) dipakai untuk menyatakan tempat berada.

Contoh di atas, berbeda dengan contoh berikut ini. 
(13a) (...) jalan besar di mana bus dan angkutan kota lewat, berjarak 1,5 $\mathrm{km}$ dan tidak ada becak atau ojek. $(\mathrm{Kr} / 367 / 58)$

(13b) (...) jalan besar bus dan angkutan kota lewat, berjarak $1,5 \mathrm{~km}$ dan tidak ada becak atau ojek.

Dalam contoh (13a) kehadiran $d i$ mana bersifat wajib karena jika di mana dihilangkan, kalimat (13a) menjadi tidak gramatikal seperti pada contoh (13b). Dalam contoh contoh (13a) di mana semata-mata menunjuk kembali keterangan tempat yang telah disebutkan lebih dahulu dalam permulaan kalimat. Kalimat semacam ini sering dijumpai dalam pemakaiannya, terutama dalam penterjemahan oleh penutur yang menguasai dua bahasa atau lebih. Dalam bahasa hal semacam ini disebut dengan istilah interfensi, yaitu pemakaian suatu kaidah bahasa ke dalam bahasa lain. Dalam contoh (13a) di mana tersebut merupakan terjemahan dari kata where dalam bahasa Inggris. Jika di mana dalam contoh (13a) dihilangkan akan mengubah kegramatikalan kalimat. Hal ini berarti kehadiran di mana dipakai untuk menggantikan kata tempat. Jika di mana disubstitusi dengan tempat, contoh (13a) akan menjadi

(13c) (...) jalan besar tempat bus dan angkutan kota lewat, berjarak $1,5 \mathrm{~km}$ dan tidak ada becak atau ojek.

Variasi mana lain yang merupakan pengaruh bahasa asing juga masih banyak dijumpai, contoh:

(14a) Tiga hotel ukuran internasional dewasa ini dipersiapkan di Jakarta dengan mana pada tahun depan akomodasi hotel untuk turis ditambah.

(15a) Kita harus memikirkan bentuk tindakan itu untuk mana pemerintahlah yang menentukan.
Dengan mana dalam contoh (14a) dan untuk mana dalam contoh (15a) dapat disubstitusikan dengan dan sehingga contoh (14a) dan (15a) akan berubah menjadi

(14b) Tiga hotel ukuran internasional dewasa ini dipersiapkan di Jakarta dan pada tahun depan akomodasi hotel untuk turis ditambah.

(15b) Kita harus memikirkan bentuk tindakan itu dan pemerintahlah yang menentukan.

Kehadiran dari mana dalam kalimat deklaratif ada yang bersifat wajib ada yang bersifat opsional, contoh

(16a) Saya tidak peduli dari manakah dia.

(16b) Saya tidak peduli dia.

Dalam contoh (16a) kehadiran dari manakah bersifat wajib. Contoh (16b) merupakan kalimat yang gramatikal, tetapi bukan merupakan parafrasa (16a). Dengan demikian, contoh (16b) bukan merupakan bukti bahwa dari manakah dalam contoh (16a) bersifat opsional.

Contoh di atas, berbeda dengan contoh di bawah ini.

(17a) Saya tidak mengerti dari mana asalnya.

(17b) Saya tidak mengerti asalnya.

Dalam contoh (17a) kehadiran dari mana bersifat opsional karena diikuti oleh kata asal. Dari mana dalam contoh (17a) menyatakan makna 'asal'. Dengan demikian, dari mana dalam contoh (17a) dapat dihilangkan menjadi pada contoh (17b). 
Kehadiran bagaimana dalam kalimat deklaratif ada yang bersifat wajib ada yang bersifat opsional, contoh

(18a) Mereka menelusuri bagaimana proses penyelesaian masalah tersebut.

(18b) Mereka menelusuri proses penyelesaian masalah tersebut.

Dalam contoh (18a) bagaimana diikuti oleh proses dalam kalimat deklaratif kehadirannya bersifat opsional karena jika bagaimana dihilangkan tidak mengubah kegramatikalan kalimat, seperti pada contoh (18b). Jika kata proses dihilangkan maka bagaimana harus hadir.

\section{SIMPULAN}

Dari uraian di atas, dapat disimpulkan bahwa apa dan mana serta bentuk tuturannya jika terdapat dalam kalimat deklaratif bukan merupakan interogativa Kehadiran apa dan mana serta bentuk tuturannya dalam kalimat deklaratif ada yang bersifat wajib ada yang bersifat opsional Bersifat opsional jika dalam kalimat deklaratif apa dan mana serta bentuk tuturannya diikuti atau didahului oleh kata yang mempunyai makna yang sama. Dalam contoh di atas misalnya mengapa didahului oleh sebab.

\section{DAFTAR PUSTAKA}

Alwi, Hasan, et al. 1993. Tata Bahasa Baku Bahasa Indonesia. Edisi ketiga. Jakarta: Balai Pustaka.

Kencono, Djoko (ed.). 1982. Dasar-Dasar Linguistik Umum. Jakarta:FSUI.

Ramlan, M. 1987. Ilmu Bahasa Indonesia sintaksis. Yogyakarta: CV Kaaryono.
Surono. 2011. Dasar-Dasar Analisis Frasa, Kalimat, dan Teks. Jurusan Sastra Indonesia Fakultas Ilmu Budaya Universitas Diponegoro

Tarigan, Henry Guntur. 1984.Pengajaran Sintaksis. Bandung:Angkasa 